\title{
THE VALUE OF INJURY SEVERITY SCORE AND ABBREVIATED INJURY SCALE IN THE MANAGEMENT OF TRAUMATIC INJURIES OF PARENCHYMAL ABDOMINAL ORGANS
}

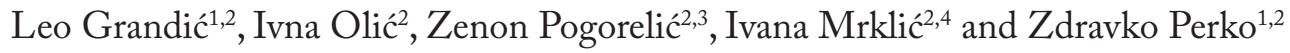 \\ ${ }^{1}$ Department of Surgery, University Hospital of Split; ${ }^{2}$ University of Split, School of Medicine; \\ ${ }^{3}$ Department of Pediatric Surgery, ${ }^{4}$ Department of Pathology, University Hospital of Split, Split, Croatia

\begin{abstract}
SUMMARY - The aim of this study was to investigate the influence of etiology, types of injury, levels of consciousness and the Injury Severity Score (ISS) and Abbreviated Injury Scale (AIS) values on the selection of treatment modality and survival in patients with injuries of parenchymal abdominal organs. Case records of 224 patients treated for traumatic injury of parenchymal abdominal organs from January 2003 until December 2015 were reviewed. The values of ISS and AIS of injury severity were calculated and compared to the values obtained according to the etiology, state of consciousness and survival. Of the 224 patients, $172(76.8 \%)$ were treated by surgical approach and $52(23.2 \%)$ were treated conservatively. The mean patient age was $40.1 \pm 18.3$ years. There were $97(43.3 \%)$ polytrauma cases. Of the 224 injured patients, $143(63.8 \%)$ were treated with transfusions of blood products. Two hundred and six (92\%) patients survived. The mean AIS and ISS values were significantly lower in patients that survived (AIS=3; ISS $=28)$ than in those that died (AIS=5; ISS $=34)(p<0.001)$. There was a statistically significant difference in AIS and ISS values between conscious (AIS=2.7; ISS $=25.9)$ and unconscious (AIS=3.2; ISS=33) patients $(\mathrm{p}<0.001)$. Of the 224 patients that did not survive, 18 (8\%) were hemodynamically unstable. Survival depended on hemodynamic stability at admission; the ISS and AIS values were associated with the injuries and state of consciousness at admission. Hemodynamic stability, state of consciousness, and ISS and AIS values were the quality predictors of survival after abdominal traumatic injury.
\end{abstract}

Key words: Abdominal injuries; Injury Severity Score; Multiple trauma; Croatia

\section{Introduction}

Abdominal injury is a common cause of morbidity and mortality in all age groups ${ }^{1-5}$. Diagnosis and treatment procedures are one of the biggest challenges in surgery. The causes of mortality due to abdominal injuries are basically severe bleeding and sepsis ${ }^{1}$. Nonoperative management of blunt abdominal solid organ injuries has become the standard of care $^{2,3}$. However,

Correspondence to: Asst. Prof. Zenon Pogorelic, MD, PhD, Department of Pediatric Surgery, Split University Hospital Centre, Spinčićeva 1, HR-21000 Split, Croatia

E-mail: zpogorelic@gmail.com

Received March 1, 2017, accepted June 27, 2017 routine surgical exploration remains the standard practice for all penetrating solid organ injuries ${ }^{2}$, but all patients with injuries to the solid organs of the abdomen who are hemodynamically stable should be considered candidates for nonoperative management after the injuries have been staged by abdominal computed tomography $(\mathrm{CT})^{3}$. These patients must remain under the care of experienced trauma surgeons because the CT stage of the injury might not always predict which patients require laparotomy. Trauma surgeons can recognize the presence of an associated hollow viscus injury in need of repair and also will be readily available to operate if the nonoperative approach fails ${ }^{3-7}$. For the purpose of evaluating physiological condition and an- 
atomic injury, a scoring system (Injury Severity Score, ISS) combined with Abbreviated Injury Scale (AIS) have been used ${ }^{4,6}$.

Hence, the aim of this study was to investigate the influence of etiology, types of injury, levels of consciousness, and the ISS and AIS values on the selection of treatment method and survival.

\section{Patients and Methods}

Case records of 264 patients treated for traumatic injury of parenchymal abdominal organs at Clinical Department of Surgery, Split University Hospital Centre in Split, Croatia, from January 2003 until December 2015 were reviewed. The Ethics Committee of the Split University Hospital Centre approved the study protocol.

The inclusion criteria were traumatic injuries of $\mathrm{pa}^{-}$ renchymal abdominal organs, patients aged $\geq 18$ years, both genders, and death did not occur immediately after admission. The exclusion criteria were patient aged $<18$ years, iatrogenic injuries of parenchymal abdominal organs, and traumatic injuries of the stomach but without injuries of parenchymal organs. Hence, 40 patients were excluded. The remaining 224 patients (163 male and 61 female) were divided into two groups according to treatment modality: surgical treatment, 172 patients, and conservative approach, 52 patients. The patients from both groups were further divided into two subgroups of hemodynamically stable and unstable patients. Note that hemodynamic stability is one of the most important parameters that influence the course and choice of treatment and later complications and survival. Hemodynamic stability was compared between the patients operated on and those managed conservatively. Injury complexities of each patient were rated using the AIS and ISS ${ }^{4}$. The ISS is an anatomic scoring system that provides an overall score for patients with multiple injuries. Each injury is assigned an AIS score and allocated to one of the six body regions. Only the highest AIS score in each body region is used. The 3 most severely injured body regions have their score squared and added together to produce the ISS score.

Based on these ratings, the patients were classified into polytrauma and non-polytrauma groups. The AIS and ISS scores were compared based on consciousness, hemodynamic stability, type of treatment, and survival. Complications were compared between the two

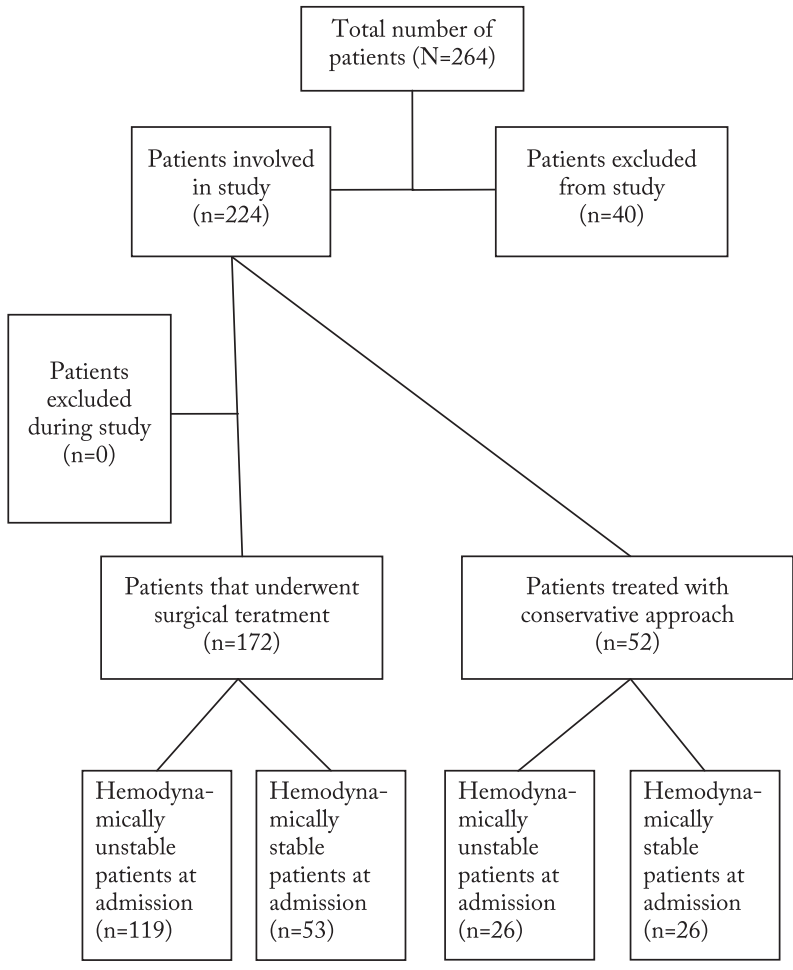

Fig. 1. Flowchart of patients with injuries of parenchymal abdominal organs.

groups. The patients who did not survive were separated and the severity of their injuries, etiology, and other parameters were analyzed and compared with the survivors.

The AIS coded injuries are divided into six body regions and injuries are assigned a six-digit score in relation to their severity, and ISS is the sum of the squares of the highest AIS values from the three most severely injured body regions. In this way, the ISS values are discontinued and vary from 0 (absence of injuries) to 75 (incompatible-with-life injury) 6 . However, only ISS $>17$ is a sign of polytrauma ${ }^{6}$. Patients with less blood loss with no associated injury and low AIS value were treated with conservative approach.

The following parameters were monitored in each patient: injury severity expressed in the unit charts of AIS 1-6, the sum of the associated injuries shown by ISS, compensation of blood products in milliliters, hemodynamic stability, followed by blood pressure and blood complications. These parameters were compared between the groups.

All procedures performed in studies involving human participants were in accordance with the ethical 
standards of the institutional and/or national research committee and with the 1964 Helsinki Declaration and its later amendments or comparable ethical standards. For this type of study, formal consent is not required.

Informed consent was obtained from all individual participants included in the study.

\section{Statistics}

The data obtained were analyzed using Student's t-test and Mann-Whitney test (SPSS, version 13.0, Chicago, IL, USA) and Microsoft Excel for Windows Version 11.0 (Microsoft, Redmond, WA, USA). The level of statistical significance was set at $\mathrm{p}<0.05$.

\section{Results}

The mean age of the 224 patients was $35.5 \pm 18.3$ years. Ninety-seven (43.3\%) of them had ISS $>17$,

Table 1. Characteristics of patients with traumatic injuries of parenchymal abdominal organs

\begin{tabular}{|l|l|}
\hline Patient data & $(\mathrm{N}=224)$ \\
\hline $\begin{array}{l}\text { Age (yrs; median, range) } \\
\text { Gender: }\end{array}$ & $35.5(17-87)$ \\
$\quad$ male, $\mathrm{n}(\%)$ & $164(72.8)$ \\
female, $\mathrm{n}(\%)$ & $60(27.2)$ \\
Polytrauma, $\mathrm{n}(\%)$ & $97(43.3)$ \\
Conscious, $\mathrm{n}(\%)$ & $165(73.7)$ \\
Survivors, $\mathrm{n}(\%)$ & $206(92)$ \\
Transfusion, $\mathrm{n}(\%)$ & $143(77.7)$ \\
\hline
\end{tabular}

hence they were polytraumatized patients. Of the 224 injured patients, $143(63.8 \%)$ patients were treated with transfusions of blood products and 206 patients survived. Patient characteristics are shown in Table 1. Spleen injury was present in 159 (71\%) patients. Rupture was the most common injury of the spleen, found in 130 (58\%) patients. Liver injury was found in 93 $(41.5 \%)$ patients, usually rupture $(n=44 ; 19.6 \%)$. Thirty-one (13.8\%) patients had kidney injuries, mostly rupture $(n=12 ; 5.4 \%)$. Pancreas injury was present in $13(5.8 \%)$ patients, contusion being the most common injury $(\mathrm{n}=7 ; 3.1 \%)$ (Table 2).

There was no statistically significant age difference between patients with and those without spleen injury $(40.5 \pm 18.072$ vs. $39.30 \pm 19.09$ years; $\mathrm{p}=0.670)$. The same applies to the injuries of other abdominal organs. Traffic accident was the most common cause of abdominal trauma of parenchymal organs $(n=133$; 59.4\%). Patients having sustained traffic accidents were younger. There was a statistically significant age difference between patients having and having not

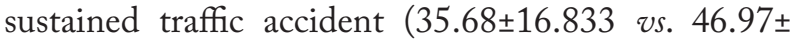
18.832 years; $\mathrm{p}<0.001)$.

There was no statistically significant difference in AIS and ISS between patients having participated in traffic accidents and those injured by falls (AIS 3; ISS 29 vs. AIS 3; ISS 26; $p=0.545$ ). Traffic accidents mostly caused injuries of complexity 3 with the median AIS value of 3 (range, 1-6) and ISS of 29 (range, 17-68). For puncture injuries, the median AIS was 2 (range, 1-4), and ISS was not calculated since there was no polytrauma. For injuries caused by falls, the median AIS was 3 (range, 1-4) and ISS was 26 (range, 17-34).

Table 2. Types and frequency of traumatic injuries of parenchymal abdominal organs

\begin{tabular}{|l|l|l|l|l|l|}
\hline \multirow{2}{*}{ Parameter } & \multicolumn{4}{|c|}{ Organ } & \\
\cline { 2 - 6 } & $\begin{array}{l}\text { Liver } \\
\mathrm{n}(\%)\end{array}$ & $\begin{array}{l}\text { Spleen } \\
\mathrm{n}(\%)\end{array}$ & $\begin{array}{l}\text { Pancreas } \\
\mathrm{n}(\%)\end{array}$ & $\begin{array}{l}\text { Kidney } \\
\mathrm{n}(\%)\end{array}$ & Total \\
\hline Rupture & $44(19.6)$ & $130(58)$ & $5(2.2)$ & $12(5.4)$ & 191 \\
Hematoma & $13(5.8)$ & $9(5.7)$ & 0 & $2(0.9)$ & 24 \\
Lesion & $9(4)$ & $1(0.6)$ & $1(0.4)$ & 0 & 11 \\
Laceration & $18(8)$ & $14(8.8)$ & 0 & $5(2.2)$ & 37 \\
Conquasation & $3(1.3)$ & $4(2.5)$ & 0 & $6(2.7)$ & 13 \\
Contusion & 0 & $1(0.6)$ & $7(3.1)$ & $6(2.7)$ & 14 \\
Puncture wound & $5(2.2)$ & 0 & 0 & 0 & 5 \\
Gunshot wound & $1(0.4)$ & 0 & 0 & 0 & 1 \\
Total & $93(41.5)$ & $159(71)$ & $13(5.8)$ & $31(13.8)$ & $296(132)$ \\
\hline
\end{tabular}

Note: 97 patients were polytraumatized 
Table 3. AIS and ISS in correlation with the state of consciousness at admission

\begin{tabular}{|l|l|l|l|}
\hline Parameter & Conscious & Unconscious & $\mathrm{p}^{*}$ \\
\hline $\begin{array}{l}\text { AIS, median } \\
\text { (range) }\end{array}$ & $2.7(1-6)$ & $3.21(1-6)$ & $<0.001$ \\
\hline $\begin{array}{l}\text { ISS, median } \\
\text { (range) }\end{array}$ & $25.9(17-75)$ & $33.0(17-108)$ & $<0.001$ \\
\hline
\end{tabular}

*t-test; AIS = Abbreviated Injury Scale; ISS = Injury Severity Score
The mean AIS and ISS values were significantly lower in patients that survived than in those that died (AIS=3; ISS=28 vs. AIS=5; ISS=34; $\mathrm{p}<0.001$ ). Specifically, those that survived had lower AIS and ISS values (Table 5).

Of the 224 patients, 19 (8.5\%) had complications after treatment, including postoperative intra-abdominal hemorrhage ( $n=4 ; 21 \%)$, bronchopneumonia $(n=8$; $42 \%)$, subphrenic abscess $(n=4 ; 21 \%)$, and so-called

Table 4. Method and frequency of treatment of traumatic injuries to abdominal organs

\begin{tabular}{|l|l|l|l|l|}
\hline Method of treatment & $\begin{array}{l}\text { Spleen } \\
\mathrm{n}(\%)\end{array}$ & $\begin{array}{l}\text { Liver } \\
\mathrm{n}(\%)\end{array}$ & $\begin{array}{l}\text { Kidney } \\
\mathrm{n}(\%)\end{array}$ & $\begin{array}{l}\text { Pancreas } \\
\mathrm{n}(\%)\end{array}$ \\
\hline Splenectomy & $105(66)$ & $/$ & $/$ & $/$ \\
Splenorrhaphy & $4(2.5)$ & $/$ & $/$ & $/$ \\
Suture & $15(9.4)$ & $50(53.8)$ & $3(9.7)$ & $4(30.8)$ \\
Hemostasis & $4(2.5)$ & $6(6.4)$ & $/$ & $1(7.6)$ \\
Pancreatectomy & $/$ & $/$ & $/$ & $4(30.8)$ \\
Hepatectomy & $/$ & $1(1.1)$ & $/$ & $/$ \\
Nephrectomy & $/$ & $/$ & $9(29)$ & \\
Conservative & $3(19.6)$ & $36(38.7)$ & $19(61.3)$ & $4(30.8)$ \\
Total & $159(100)$ & $93(100)$ & $31(100)$ & $13(100)$ \\
\hline
\end{tabular}

Table 5. AIS and ISS values in correlation with patient survival

\begin{tabular}{|l|l|l|l|}
\hline \multicolumn{4}{|c|}{ Number of patients and median (range) of scores } \\
\hline Parameter & $\begin{array}{l}\text { Died } \\
(\mathrm{n}=18)\end{array}$ & $\begin{array}{l}\text { Survived } \\
(\mathrm{n}=206)\end{array}$ & $\mathrm{p}$ \\
\hline AIS & $5(3-6)$ & $3(1-6)$ & $<0.001$ \\
\hline ISS & $34(17-108)$ & $28(17-75)$ & $<0.001$ \\
\hline
\end{tabular}

*Mann-Whitney test; AIS = Abbreviated Injury Scale; ISS = Injury Severity Score

In patients with gunshot injuries, the median AIS was 4 (range, 2-6). The median AIS and ISS values were significantly lower in conscious patients (AIS $=2.7$; ISS=25.9) than in unconscious patients (AIS $=3.21$; ISS=33.0) $(\mathrm{p}<0.001)$. Conscious patients had higher AIS and ISS values (Table 3 ).

On admission, 145 (64.7\%) of 244 patients were hemodynamically unstable and 119/145 (82\%) patients were treated surgically; however, 172 (76.8\%) of the 244 patients were operated on. Splenectomy was the most commonly performed operation (Table 4). bitemporal hemorrhage in subcapsular spleen hematoma $(\mathrm{n}=3 ; 16 \%)$. The patients that died were mostly hemodynamically unstable on admission ( $\mathrm{n}=15 ; 83.3 \%)$. Most of them had spleen injuries $(n=12 ; 66 \%)$, followed by liver ( $\mathrm{n}=11 ; 61.1 \%)$, kidney $(\mathrm{n}=5 ; 27.8 \%)$ and pancreas $(n=4 ; 22.2 \%)$ injuries.

Considering the very small number of deceased patients with complications, there was no statistically significant difference in the efficiency between surgical $(\mathrm{n}=10 ; 55 \%)$ and conservative $(\mathrm{n}=8 ; 45 \%)(\mathrm{p}=0.61)$ treatment.

\section{Discussion}

Abdominal trauma is the leading cause of morbidity and mortality in all age groups. Identification of patients with significant intra-abdominal injury is often challenging and is important to improve outcome. Assessment of hemodynamic stability is the most important initial concern in the evaluation of a patient with abdominal trauma ${ }^{5}$. In the hemodynamically unstable patient, rapid evaluation for hemoperitoneum can be ac- 
complished by means of diagnostic peritoneal lavage or focused assessment with sonography for trauma. The goal is to recognize polytraumatized patients where extra-abdominal injuries may change abdominal findings. In blunt abdominal trauma, including severe solid organ injuries, selective nonoperative management has become the standard of care. Nonoperative management strategies are based on CT scan diagnosis and hemodynamic stability of the patient ${ }^{3,8}$. In this study, there were $43.3 \%$ of polytrauma cases. Most of the patients (76.8\%) were treated by surgical approach and a minority of them (23.2\%) conservatively. Of 224 injured patients, many required blood transfusions and most survived. The mean AIS and ISS values were significantly lower in patients that survived than in those that died. There was a statistically significant difference in AIS and ISS values between conscious and unconscious patients. $\mathrm{Pa}-$ tients that did not survive (8\%) were mainly hematologically unstable.

In this study, no statistically significant difference between treatment modalities was found because of the very small number of deceased patients. In the literature, the rates of survival and complications are almost equal for surgical and conservative treatments ${ }^{8,9}$. Most patients in this study were hemodynamically unstable on admission, and it was the reason why a smaller number of patients were treated conservatively. Most authors prefer conservative treatment, especially in the management of splenic injury ${ }^{9,10}$, and a lower number of complications is reported as compared with surgical treatment ${ }^{10,11}$. Specifically, hemodynamically stable patients with lower AIS and ISS values generally should be treated with a conservative approach, and such a treatment protocol was followed by surgeons in this study. Patients that underwent surgical treatment had the higher percentage of complications and poorer survival outcome as compared with patients undergoing conservative treatment ${ }^{4}$.

Although some authors have reported conservative treatment in patients with massive hemoperitoneum, in our institution massive hemoperitoneum is an indication for laparotomy ${ }^{11-14}$. The patients that did not survive had very serious injuries and mostly were highly polytraumatized, with high ISS values.

Nowadays, quite a number of authors report the use of laparoscopy for diagnostic and therapeutic purpose ${ }^{12}$. We do not usually treat patients with traumatic injury of parenchymal organs with laparoscopic ap- proach because in urgent situations, when the surgeon is confronted with massive hemorrhage, laparoscopy is not always feasible ${ }^{15-17}$.

Spleen is the most commonly damaged organ in blunt abdominal trauma, although some authors found the liver to be the first by the number of traumatic injuries $^{7}$. In this study, spleen was also the most commonly injured organ. Because of the spleen ability to bleed profusely, a ruptured spleen can be life-threatening, resulting in shock. However, unlike the liver, penetrating trauma to the spleen, pancreas and kidneys does not present as much of immediate threat of shock unless there is laceration of a major blood vessel supplying the organs.

In our study, we found that patients that were unconscious on admission were mostly hemodynamically unstable and were surgically treated in most cases. In their multicenter study, Velmahos et al. ${ }^{13}$ report on the importance of associated spleen injury and collateral brain injury. Isolated abdominal injuries are rarely fatal. Associated injuries, especially head injuries, increase the risk of failure of nonoperative management ${ }^{13}$. Nowadays, the spleen-preserving approach is preferred to splenectomy whenever possible. Wrapping injured spleen into Dexson mesh is an appropriate substitution to splenectomy during massive hemorrhages ${ }^{18}$. Our study showed splenectomy to be the best solution for massive hemorrhages and hemodynamically unstable patients. Spleen-preserving procedures also are efficient but cannot be applied in each patient ${ }^{18,19}$.

We found that pancreas was a rarely injured organ and pancreatic injuries were most commonly caused by bicycle accidents in children and vehicular accidents in adults. Our findings also confirmed data from other studies which state that pancreas is a rarely injured organ and rarely found as an isolated injury ${ }^{14,15}$. Pancreatic injuries usually are accompanied by other injuries in adults. According to Schroeppel and Croce, non-surgical approach is very successful in certain patient populations, but traumatic pancreatic injury should primarily be surgically treated. In their study, two-thirds of patients with injuries of the pancreas were surgically treated (by partial pancreatomy or stitching $)^{14}$. The method of treatment ultimately depends on the status of the main pancreatic duct, the concomitant injuries in the abdomen (pancreatic injury is rarely an isolated injury), and hemodynamic stability ${ }^{15}$. 
The kidneys may also be injured; they are somewhat but not completely protected by the ribs. Kidney lacerations and contusions may also occur. Results of this study showed that traumatic kidney injuries were treated conservatively with high success in most cases, which is in agreement with the literature ${ }^{17}$. Nephrectomy should only be performed in patients with renal vessel injuries and massive hemorrhage, or in cases of traumatic amputation of the kidney.

As far as liver injuries are concerned, our results showed that these injuries mostly were surgically treated, although a significant number of patients were cured conservatively. Non-surgical treatment is a choice for hemodynamically stable patients ${ }^{8}$. The liver is injured in about five percent of all people admitted to the hospital for trauma and present a serious risk for shock because liver tissue is delicate and has large blood supply and capacity ${ }^{20,21}$. Results obtained by the application of 'packing' and better control of arterial hemorrhaging are very good ${ }^{8,20,21}$. Liver transplantation has been described in the literature as an extreme intervention in rare cases of severe liver trauma ${ }^{16}$. In our study, only one patient was treated with hepatectomy and liver transplantation because of massive hemorrhaging.

\section{Conclusion}

Patients with traumatic injuries of parenchymal abdominal organs were mostly young males involved in traffic accidents. Older patients were injured due to fall. Polytraumatized patients with higher ISS and AIS values had less chance of survival and most of them were operated on. Hemodynamic status of the patient on admission, ISS and AIS values, and other organ injuries, as well as the state of consciousness on admission influenced the chances of survival.

\section{References}

1. Tantry TP, Kadam D, Shetty P, Adappa KK, Muralishankar B, Shenoy SP. Penetrating abdominal injury in a polytrauma patient: anaesthetic challenges faced. J Anaesthesiol Clin Pharmacol. 2011;27:272-4. doi: 10.4103/0970-9185.81846

2. Demetriades D, Hadjizacharia P, Constantinou C, Brown C, Inaba K, Rhee P, Salim A. Selective nonoperative management of penetrating abdominal solid organ injuries. Ann Surg. 2006;244:620-8. doi: 10.1097/01.sla.0000237743.22633.01

3. Knudson MM, Maull KI. Nonoperative management of solid organ injuries. Past, present, and future. Surg Clin North Am. 1999;79:1357-71.
4. Palmer CS, Franklyn M, Read-Allsopp C, McLellan S, Niggemeyer LE. Development and validation of a complementary map to enhance the existing 1998 to 2008 Abbreviated Injury Scale map. Scand J Trauma Resusc Emerg Med. 2011;19:29. doi: 10.1186/1757-7241-19-29.

5. Loggers SA, Koedam TW, Giannakopoulos GF, Vandewalle E, Erwteman M, Zuidema WP. Definition of hemodynamic stability in blunt trauma patients: a systematic review and assessment amongst Dutch trauma team members. Eur J Trauma Emerg Surg. 2016. doi: 10.1007/s00068-016-0744-8

6. Butcher N, Balogh ZJ. AIS $>2$ in at least two body regions: a potential new anatomical definition of polytrauma. Injury. 2012;43:196-9. doi: 10.1016/j.injury.2011.06.029

7. Gür S, Orsel A, Atahan K, Hökmez A, Tarcan E. Surgical treatment of liver trauma (analysis of 244 patients). Hepatogastroenterology. 2003;50:2109-11.

8. Hashemzadeh SH, Hashemzadeh KH, Dehdilani M, Rezaei S. Non-operative management of blunt trauma in abdominal solid organ injuries: a prospective study to evaluate the success rate and predictive factors of failure. Minerva Chir. 2010; 65:267-74.

9. Jalovec LM, Boe BS, Wyffels PL. The advantages of early operation with splenorrhaphy versus nonoperative management for the blunt splenic trauma patient. Am Surg. 1993;59: 698-704.

10. Pachter HL, Guth AA, Hofstetter SR, Spencer FC. Changing patterns in the management of splenic trauma: the impact of nonoperative management. Ann Surg. 1998;227:708-17. doi: 10.1097/00000658-199805000-00011

11. Goan YG, Huang MS, Lin JM. Nonoperative management for extensive hepatic and splenic injuries with significant hemoperitoneum in adults. J Trauma. 1998;45:360-4. doi: 10.1097/00005373-199808000-00026

12. Kaban GK, Novitsky YW, Perugini RA, Haveran L, Czerniach D, Kelly JJ, Litwin DE. Use of laparoscopy in evaluation and treatement of penetrating and blunt abdominal injuries. Surg Innov. 2008;15:26-31. doi: 10.1177/1553350608314664.

13. Velmahos GC, Zacharis N, EmhoffTA, Feeney JM, Hurst JM, Crookes BA, Harrington DT, Gregg SC, Brotman S, Burke PA, Davis KA, Gupta R, Winchell RJ, Desjardins S, Alouidor R, Gross RI, Rosenblatt MS, Schulz JT, Changal Y. Management of the most severely injured spleen: a multicenter study of the Research Consortium of New England Centers for Trauma. Arch Surg. 2010;145:456-60. doi: 10.1001/archsurg.2010.58

14. Schroeppel TJ, Croce MA. Diagnosis and management of blunt abdominal solid organ injury. Curr Opin Crit Care. 2007;13:399-404. doi: 10.1097/MCC.0b013e32825a6a32

15. Jurić I, Pogorelić Z, Biočić M, Todorić D, Furlan D, Šušnjar T. Management of blunt pancreatic trauma in children. Surg Today. 2009;39:115-9. doi: 10.1007/s00595-008-3823-6

16. Delis SG, Bakoyiannis A, Selvaggi G, Weppler D, Levi D, Tzakis AG. Liver transplantation for severe hepatic trauma: experience from a single center. World J Gastroenterol. 2009;15:1641-4. doi:10.3748/wjg.15.1641 
17. Simmons JD, Haraway AN, Schmieg RE Jr, Duchesne JD. Blunt renal trauma and the predictors of failure of non-operative management. J Miss State Med Assoc. 2010;51:131-3.

18. Berry MF, Rosato EF, Williams NN. Dexon mesh splenorrhaphy for intraoperative splenic injuries. Am Surg. 2003;69:176.

19. Grandić L, Pogorelić Z, Banović J, Perko Z, Boschi V, Ilić N, Tripković A, Šarić D. Advantages of the spared surgical treatment of the spleen injuries in the clinical conditions. Hepatogastroenterology. 2008;55:2256-8.
20. Richardson JD, Franklin GA, Lukan JK, Carrillo EH, Spain DA, Miller FB, Wilson MA Jr, Polk HC, Flint LM. Evolution in the management of hepatic trauma: a 25 -year perspective. Ann Surg. 2000;232:324-30.

21. Jurić I, Smoje P, Pogorelić Z, Todorić D, Jukić M, Furlan D. Factors of parenchymal organ injury treatment outcome in children at Department of Pediatric Surgery, Split University Hospital Center during the 2000-2015 period. Paediatr Croat. 2016. doi: 10.13112/PC.2017

Sažetak

\title{
ULOGA OCJENSKIH LJESTVICA INJURY SEVERITY SCORE I ABBREVIATED INJURY SCALE U LIJEČENJU TRAUMATSKIH OZLJEDA PARENHIMSKIH ORGANA TRBUHA
}

\author{
L. Grandic, I. Olic, Z. Pogorelic, I. Mrklići Z. Perko
}

Cilj ovoga rada bio je istražiti utjecaj etiologije, vrste ozljede, stanja svijesti te vrijednosti ocjenskih ljestvica Injury Severity Score (ISS) i Abbreviated Injury Scale (AIS) na izbor načina liječenja i preživljenje u bolesnika s traumatskim ozljedama trbuha. Povijesti bolesti 224 bolesnika liječenih zbog traumatskih ozljeda parenhimskih organa u razdoblju od siječnja 2003. do prosinca 2015. godine retrospektivno su pregledane. Izračunate su vrijednosti ISS i AIS i uspoređene s vrstom ozljede, stanjem svijesti i etiologijom nastanka ozljede. Od ukupno 224 bolesnika, $172(76,8 \%)$ ih je liječeno kirurškim pristupom, a 52 $(23,2 \%)$ konzervativno. Srednja dob bila je $40,1 \pm 18,3$ godina. Devedeset sedam $(43,3 \%)$ bolesnika bilo je politraumatizirano. Od ukupnog broja bolesnika $143(63,8 \%)$ ih je liječeno transfuzijama krvnih pripravaka. Ukupno je preživjelo 206 (92\%) bolesnika. Srednje vrijednosti AIS i ISS bile su značajno niže u bolesnika koji su preživjeli (AIS=3; ISS=28) u odnosu na one koji su umrli (AIS=5; ISS=34) ( $<<0,001)$. Također je utvrđena statistički značajna razlika u vrijednostima AIS i ISS između bolesnika koji su bili pri svijesti (AIS=2,7; ISS=25,9) i onih koji su kod prijma bili bez svijesti (AIS=3,2; ISS=33) ( $<<0,001)$. Od ukupnog broja bolesnika 18 (8\%) bolesnika koji nisu preživjeli bili su hemodinamski nestabilni. Preživljenje ovisi o hemodinamskoj stabilnosti pri prijmu, a vrijednosti ISS i AIS ovise o vrsti ozljeda i stanju svijesti pri prijmu. Hemodinamska stabilnost, stanje svijesti, ISS i AIS vrijednosti pokazali su se kao prediktori preživljenja u bolesnika s traumatskim ozljedama trbuha.

Ključne riječi: Abdominalne ozljede; Ozljeda, težina - ljestvica; Politrauma; Hrvatska 